\title{
The Effect of Changing Background Emissions on External Cost Estimates for Secondary Particulates
}

\author{
L.L.R. Int Panis
}

Integrated Environmental Studies, Flemish Institute for technological Research (VITO), Belgium

\begin{abstract}
This paper discusses the importance of background concentrations of $\mathrm{NH}_{3}, \mathrm{SO}_{2}$ and $\mathrm{NO}_{\mathrm{x}}$ for the estimation of environmental external costs of secondary particulates. A modified version of the ECOSENSE software was developed within the ongoing series of European ExternE projects, devoted to the assessment of energy related environmental external costs. Using the Windrose Trajectory Model the yearly average concentrations of pollutants at ground level was calculated based on average meteo data and a simple scheme of atmospheric reactions. After this, epidemiological exposureresponse functions are applied to determine the impact on the receptors. Finally, the calculated physical impacts are monetized on the basis of selected economic evaluations. The fact that estimates of external costs of incremental emissions of $\mathrm{NO}_{\mathrm{x}}$ and $\mathrm{SO}_{2}$ will increase when background emissions decrease is the most important new result. The choice of relevant background emissions is therefore essential to obtain meaningful estimates of external costs.
\end{abstract}

\section{INTRODUCTION}

\section{General}

Environmental externalities from the emission of pollutants in the atmosphere are the sum of the costs (adverse impacts) that are imposed on society and the environment but not taken into account by the polluter (e.g. health effects of inhalation of secondary aerosols). The European ExternE project series is the most state-of-the-art attempt to build a consistent methodology to estimate the environmental external costs from different fuel cycles. The resulting accounting framework was implemented in the ECOSENSE software package. During several of the projects in the ExternE series, different versions of ECOSENSE were distributed to participants in order to make calculations in their own countries (E.g. the 1995 National Implementation project) [1]. This proved to be a very successful strategy leading to numerous external cost estimates in different countries being published. The software was distributed with databases including all necessary data and parameters such as meteorology, background emissions, concentration response functions and valuation data that allow the model to be used with default settings. The parameters used for modelling however are rarely discussed although this may have a large impact on the results [2]. The current European CASES project will therefore need to take these considerations into account.

\section{Regional Dispersion}

The regional dispersion model at the heart of ECOSENSE is the Windrose Trajectory Model (WTM), based on the windrose approach of the Harwell Trajectory Model. It is used to estimate the concentration and deposition of secondary acid species on a European wide scale. It was originally

\footnotetext{
*Address correspondence to this author at the Integrated Environmental Studies, Flemish Institute for technological Research (VITO), Belgium; E-mail: luc.intpanis@vito.be
}

developed at Harwell Laboratory by [3] for atmospheric nitrogen species, and extended to include sulphur species by [4]. The model is a receptor-orientated Lagrangian plume model employing an air parcel with a constant mixing height of $800 \mathrm{~m}$ moving with a representative wind speed. The results are obtained at each receptor point by considering the arrival of 24 trajectories weighted by the frequency of the wind in each $15^{\circ}$ sector. The trajectory paths are assumed to be along straight lines and are started at 96 hours from the receptor point [5]. All data required to run the Windrose Trajectory Model, including the background emissions, are provided by the ECOSENSE database. The background emissions are the total emissions from all other sources of $\mathrm{SO}_{2}$, $\mathrm{NO}_{\mathrm{x}}$ and $\mathrm{NH}_{3}$ given on a $50 \mathrm{x} 50 \mathrm{~km}$ grid covering the whole of Europe. These emissions undergo the same chemical transformations as the pollutant source that is being studied and determine the rate at which pollutants react in the atmosphere.

\section{Chemical Transformations}

Within ECOSENSE applications, the WTM is configured to resemble the atmospheric chemistry of the Harwell Trajectory Model. The chemical transformations modelled in WTM are schematically shown in Fig. (1). Through the action of highly active oxygen containing species such as ozone, primary emissions of $\mathrm{NO}$ and $\mathrm{SO}_{2}$ are converted into acids. Reactions with ammonia transform these acids into ammonium salts (ammonium nitrate and ammonium sulphate). Several chemical species occur in more than one diagram in Fig. (1) (not all relationships are shown) indicating competing reactions. Sulphuric acid is assumed to be somewhat more successful in scavenging ammonia from the atmosphere than nitric acid. All secondary species are removed from the atmosphere through wet or dry deposition, each species having its specific deposition rates.

The simple reaction scheme used by ECOSENSE does not allow the modelling of organic aerosol formation. Never- 

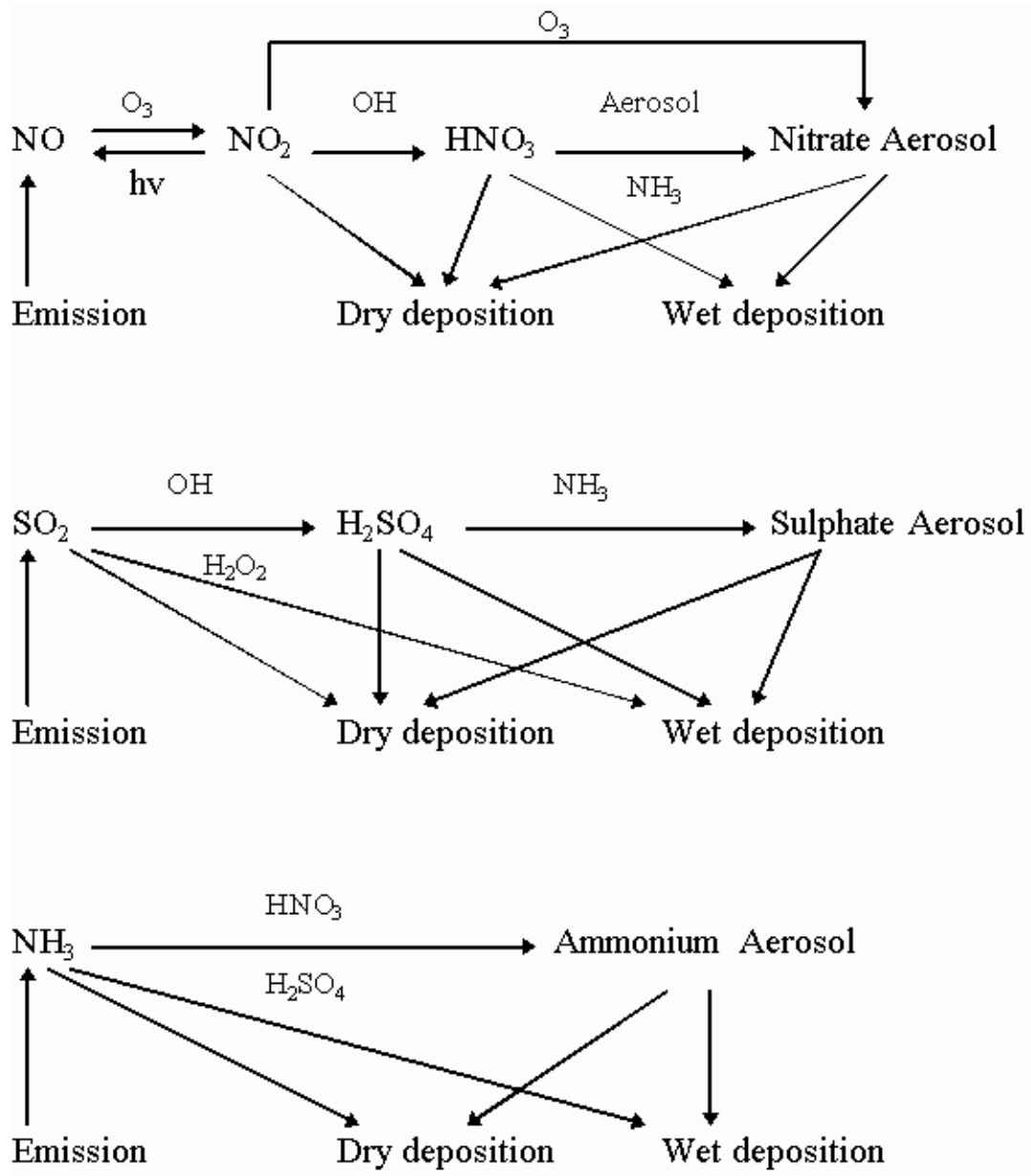

Fig. (1). Schematic view of atmospheric reactions in ECOSENSE describing the transformation of nitrogen and sulphur containing emissions into secondary aerosols (source: adapted from [4] by [5]).

theless [6] could show that (with the exception of organic aerosols) WTM was sufficiently reliable given its purpose. To test the validity of the annual average concentrations obtained by ECOSENSE they were compared with measurements as well as results of a more sophisticated model built around the chemical gas phase mechanism CACM [7] and the aerosol module MADRID 2 [8,9] which provides unprecedented accuracy for many components of the aerosol mixture. Their comparison, complicated by the large number of substances modelled by MADRID 2 and not by ECOSENSE [6], therefore focused on the total amount of secondary inorganic pollutants and found that the results of both models agreed well, especially for the fraction attributed with health effects.

\section{Health Effects of Secondary Aerosols}

It has been shown in epidemiology, but also in toxicology and medical experiments, that particles in ambient air cause adverse health effects in populations exposed to them [10]. A large number of studies have demonstrated an association between PM, respiratory and cardiovascular illnesses and increased mortality (both acute and chronic). The most important health endpoints used in ECOSENSE are summarized in the first column of Table 1. ECOSENSE uses con- centration-response functions (CRF, references in Table 1) and data on population density to estimate impacts on public health.

Table 1. Most Important Health Endpoints Included in ExternE (Summarized from [11])

\begin{tabular}{|c|c|c|}
\hline Health Endpoint & Unit & Implicated Pollutants \\
\hline $\begin{array}{c}\text { Chronic mortality } \\
{[12]}\end{array}$ & YOLL $^{5}$ & $\begin{array}{c}\text { Primary } \mathrm{PM}_{2.5} \text { (other) } \\
\text { Primary } \mathrm{PM}_{2.5}(\text { traffic) } \\
\text { Primary } \mathrm{PM}_{10}{ }^{2} \\
\text { Nitrate aerosols }{ }^{3} \\
\text { Sulphate aerosols }\end{array}$ \\
\hline $\begin{array}{c}\text { Chronic Bronchitis } \\
{[13]}\end{array}$ & Cases & $\begin{array}{c}\text { Primary } \mathrm{PM}_{2.5} \\
\text { Primary } \mathrm{PM}_{10} \\
\text { Nitrate aerosols } \\
\text { Sulphate aerosols }\end{array}$ \\
\hline No effect included & & $\begin{array}{c}\text { Nitric Acid } \\
\text { Sec. Organic aerosols }\end{array}$ \\
\hline
\end{tabular}

Assumed to cause $50 \%$ more mortality than the general $\mathrm{PM}_{25}$ mixture.

${ }^{2}$ Assumed to cause $40 \%$ less mortality than $\mathrm{PM}_{2.5}$.

${ }^{3}$ Assumed to cause $50 \%$ less mortality than $\mathrm{PM}_{10}$.

${ }^{4}$ Assumed to be equivalent to $\mathrm{PM}_{10}$ (including sulphuric acid).

${ }^{5}$ Years Of Life Lost (loss of life expectancy). 
Most of the available epidemiological studies are based on the mass of PM without any distinction of physical or chemical characteristics (acidity, solubility, ...). There is for example limited evidence for the toxicity of components like sulphates and nitrates that make up a large fraction of the mass of particulate matter in ambient air. In particular there is a lack of epidemiological studies related to nitrate aerosols because until recently this pollutant was not monitored by air pollution monitoring stations [11]. It is however crucial to quantify the external costs of source-specific contributions to ambient PM. This will improve decisions on cost-efficient abatement strategies, and will allocate the scarce resources to those emission reduction measures that yield the largest reduction in air pollution related health effects.

Therefore ExternE tried to differentiate between primary and secondary particles. In a first series of studies [14] the assumption was made that the toxicity of all sulphates was equal to that of the general $\mathrm{PM}_{2.5}$ mixture and the toxicity of particulate nitrates equal to that of $\mathrm{PM}_{10}$. This distinction between sulphates and nitrates was based only on size, noting that nitrates need other particles to condense on, whereas sulphates self-nucleate and are therefore smaller on average. The ratio of CRF slopes of $\mathrm{PM}_{10}$ to $\mathrm{PM}_{2.5}$ was taken as 0.6, because this is a typical value of the ratio of concentrations of $\mathrm{PM}_{2.5}$ and $\mathrm{PM}_{10}$ [14].

For the most recent methodological report from the ExternE series the assumptions about the toxicity of the different PM types have been adapted to the latest epidemiological and toxicological evidence. [11] state that it is now more likely than not that primary particles from combustion, more specifically from traffic are more damaging to health than other particles. For the secondary particles the evidence is less convincing. In particular for nitrates there is still not much evidence for harmful effects, whereas for sulphates quite a few studies, including the very important cohort study of [12], do find associations. Thus sulphates are now treated as $\mathrm{PM}_{10}$, and nitrates as being half as toxic as $\mathrm{PM}_{10}$. Primary particles from traffic are estimated to be 1.5 as toxic as $\mathrm{PM}_{2.5}$ and particles from other combustion sources like power plants are also treated as $\mathrm{PM}_{10}$.

\section{Implications for External Cost Estimates in the Future}

The continued use of older ECOSENSE versions today may yield results that are not compatible with the most upto-date methodology. Ever since the first model versions were distributed, important changes to the ExternE methodology have been made. Several dominant exposure-response functions (e.g. chronic mortality and chronic bronchitis) were revised a number of times and recently new empirical results for the value of a Life Year lost were introduced (e.g. $[5,11,14-16]$. While the exposure-response functions and monetary values included with the ECOSENSE software can easily be modified by the user, changing the background emissions used by the Windrose Trajectory Model is not straightforward. More recent background emissions have been compiled into ECOSENSE compatible formats, but these were not widely distributed among ECOSENSE users from previous ExternE projects (Bickel P., pers. com..). Most users therefore still use the default background emis- sions data included with the model that refer to the years 1990 or 1994. Even the ECOSENSE Pointsource 2000 version still contained 1994 background emissions albeit on a 50x50km resolution (Krewitt W., pers. comm.).

To complicate things, the emissions database for the year 1994 has meanwhile been updated by EMEP. The first version will therefore be referred to as 1994a (included with ECOSENSE) and the more recent update (used in this paper for the first time) as 1994b.

\section{MATERIALS AND METHODS}

The modeling results discussed in this paper were all obtained with the transport version of ECOSENSE [5]. These results also apply to the point source versions because the WTM parameters appear to be the same in all versions available to the author. In addition a preliminary assessment of the deposition and wash-out modelling in both versions revealed no meaningful differences [6]. The ECOSENSE software is available from the Institut für Energiewirtschaft und Rationelle Energieanwendung (IER) of the University of Stuttgart in Germany. More details can be found at: http: //www.externe.info.

ECOSENSE stores only one set of background emissions on the EUROGRID co-ordinate system, which defines equalarea projection grid cells, covering all EU and European non-EU countries in a Paradox database at a $50 \times 50 \mathrm{~km}$ resolution [17]. All versions known to us use either 1990 or 1994a EMEP emissions.

For the calculations presented here, new emissions data for the years 1990, 1994b, 2000, 2005, 2010 and 2020 were taken for the EU18 countries (including the 15 old member states as well as Iceland, Norway and Liechtenstein) from the UNECE/EMEP emission database WebDab (http: //www.emep.int). This online database was constructed to facilitate access to the emission data reported to the Convention on Long-Range Transboundary Air Pollution (CLRTAP). This data served as the basis for the preparation of six new versions of the background emissions Paradox database that were integrated to work with ECOSENSE and WTM. This involved running the model without any extra emissions to create a database with background concentrations which was then again integrated to work with ECOSENSE and WTM. Results were calculated for each dataset and used in a validation of previously published results.

\section{RESULTS}

\section{Total Background Emissions (EU18)}

Emissions of $\mathrm{SO}_{2}$ and $\mathrm{NO}_{2}$ have been decreasing considerably since 1990 (Fig. 2) and this is expected to continue for another decade. The total decrease between 1990 and 2020 is projected to be $80 \%$ for $\mathrm{SO}_{2}$ and $60 \%$ for $\mathrm{NO}_{x}$. For individual grid cells (e.g. in Belgium) the differences may be even more important.

The emissions of $\mathrm{NH}_{3}$ have decreased to a much lesser extent. Projected emissions of $\mathrm{NH}_{3}$ were not completely reported by all countries for the year 2005 and could therefore not be used in this study. This different evolution will change balance in the atmospheric chemistry and change the 


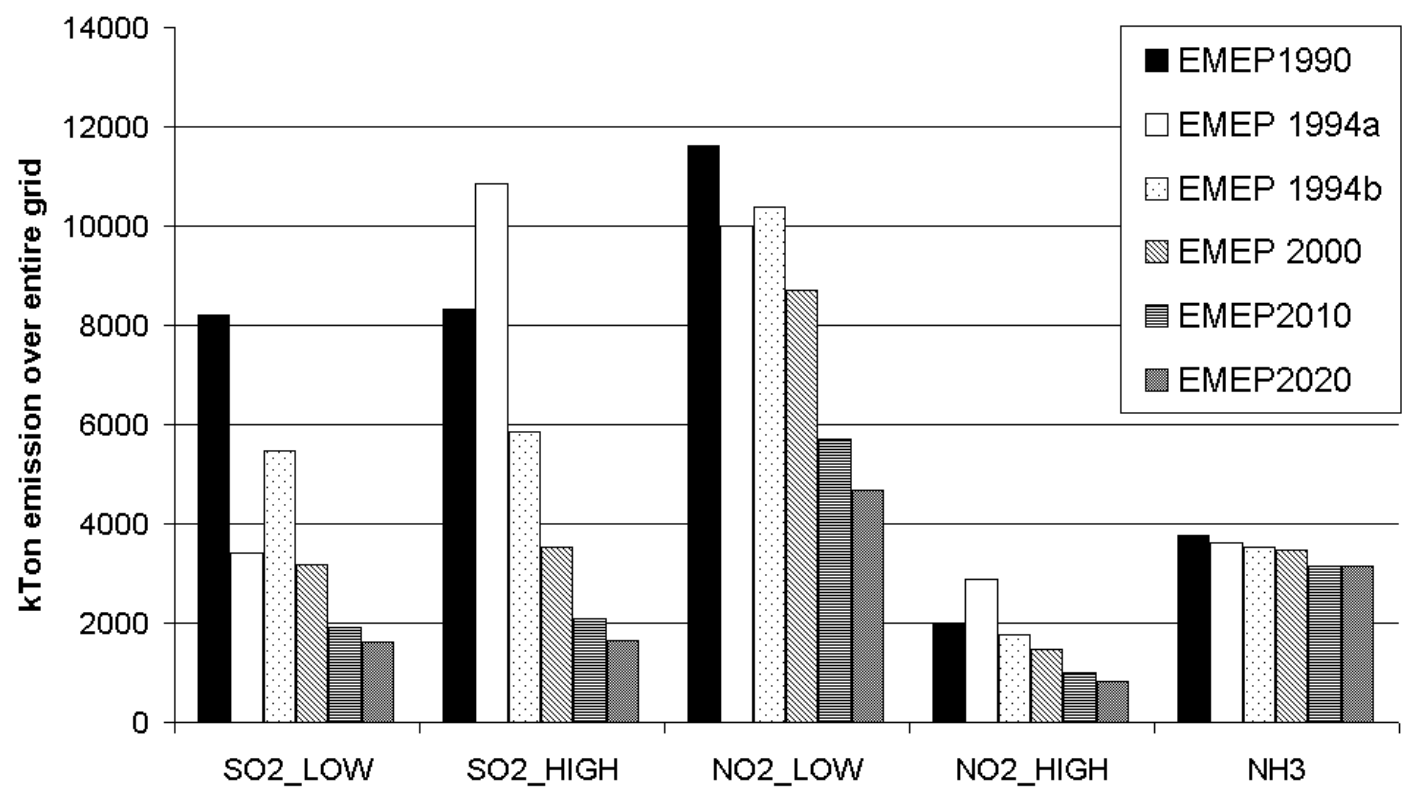

Fig. (2). Comparison of total emissions over the EMEP grid for different years.

amount of $\mathrm{SO}_{2}$ and $\mathrm{NO}_{\mathrm{x}}$ that gets converted into secondary particulate matter [18]. This effect is reproduced in a fairly simple way by the WTM reaction scheme (Fig. 1).

\section{Externalities Resulting from Secondary Aerosols}

Fig. (3) shows the results obtained with ECOSENSE for the release of 1 additional tonne of pollutant. Six runs with different background emissions were performed. The results are expressed in Euro per tonne of pollutant emitted (either $\mathrm{NO}_{\mathrm{x}}$ or $\mathrm{SO}_{2}$ ) and includes all damages caused by the secondary aerosols resulting from this primary emission.

The original results (labelled 1994a, obtained with the background emissions originally provided with ECOSENSE) are quite similar to the results obtained with the emissions for 1994 (1994b) currently distributed by EMEP. This exercise therefore constitutes an important independent validation of the ExternE-methodology. Fig. (3) also shows that costs per tonne are expected to rise significantly in the future. This effect can easily be understood from the ECOSENSE reaction scheme (Fig. 1). Because the emissions of $\mathrm{NH}_{3}$ are expected to stay at a similar level whereas $\mathrm{SO}_{2}$ emissions show a strong decrease (Fig. 2) more $\mathrm{NH}_{3}$ is left to react with sulphuric acid and transform it to ammonium sulphate.

Similarly when $\mathrm{NO}_{\mathrm{x}}$ emissions decrease significantly more $\mathrm{NH}_{3}$ is left to react with nitric acid and more nitric acid will be converted to nitrate aerosol. Since ECOSENSE only attributes health effects to the nitrate aerosol (and not to its nitric acid precursor) the cost per one tonne of $\mathrm{NO}_{\mathrm{x}}$ emitted will increase.

Model results show it to be more than twice as high in 2020 than it was in 1990. The emission of one tonne of $\mathrm{SO}_{2}$ will also lead to impacts from sulphates that are nearly twice as high in 2020 as compared to 1990.

\section{DISCUSSION}

\section{Literature}

The only similar manipulation of background emissions with ECOSENSE was done in the Green Accounting project $[5,19]$ where it was demonstrated that impacts from emissions are higher when emissions in a neighbouring country are set to zero (a test was carried out for Germany and the Netherlands). The reason for this effect is that concentrations of $\mathrm{NH}_{3}$ are higher without the emissions in the neighbouring country so that more $\mathrm{NH}_{3}$ remains available to react with local $\mathrm{SO}_{2}$ and $\mathrm{NO}_{\mathrm{x}}$ emissions to form sulphates and nitrates. The influence of German emissions on the Dutch damage estimation was about $10 \%$ and vice versa about 1 percent. In addition [19] demonstrated that the effects of emission reductions on impacts are not linear, which is entirely consistent with the results presented here (Fig. 3).

\section{Modelling Results}

It is clear from the results in Fig. (3) that ECOSENSE external cost estimates (in $€ /$ tonne of primary pollutant emitted) will rise in the future. This is due to two mechanisms in the scheme of atmospheric reactions used in the WTM module. The first effect is that more sulphuric acid is converted to ammonium sulphate when more ammonia is available. This in turn causes more $\mathrm{SO}_{2}$ to be converted to sulphuric acid. Both sulphuric acid and ammonium sulphates are attributed with adverse health effects in ECOSENSE. These health impacts from the release of 1 unit of $\mathrm{SO}_{2}$ will increase $54 \%$ between 1994(b) and 2010. On the other hand impacts from $\mathrm{SO}_{2}$ itself will be $10 \%$ lower because it gets depleted from the atmosphere. The second effect is that similarly more nitric acid is converted to ammonium nitrate when $\mathrm{NH}_{3}$ is abundant. In this way future concentrations of nitric acid will be lower and concentrations of ammonium nitrate will rise. This finding is related to the question whether nitric 


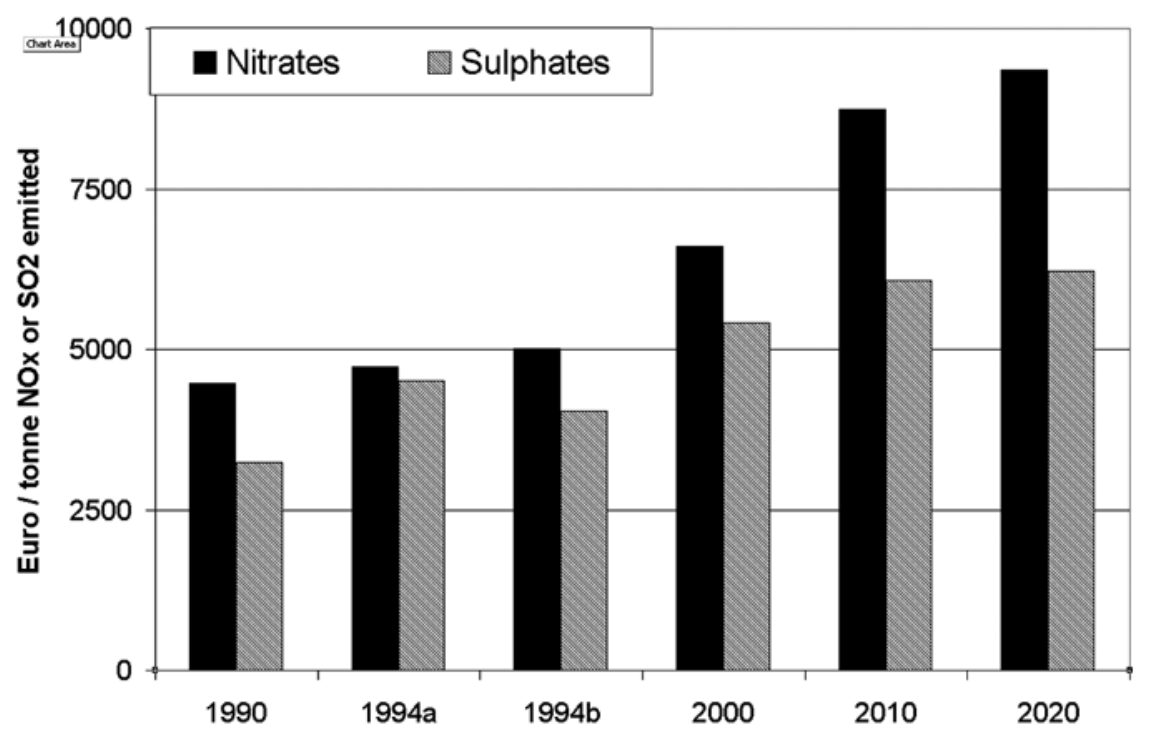

Fig. (3). Damage cost per tonne emitted under different background conditions (years).

acid is also toxic (pers. comm. A. Rabl, 2004). Unlike sulphuric acid, the tested ECOSENSE version assumes nitric acid is harmless (P. Bickel, pers. comm., 2004). This explains why impacts from this pathway are expected to show a stronger increase ( $+87 \%$ between 1994(b) and 2010). If however nitric acid is toxic, the present day impacts have been underestimated and the extra conversion of nitric acid to nitrate in the future would not have an additional effect. If nitric acid is toxic, the damage cost attributed to the emission of $\mathrm{NO}_{2}$ could be about 15 to $35 \%$ higher than with the reference assumption of ExternE. The reason why the difference is not larger lies in the high deposition velocity of $\mathrm{HNO}_{3}$ which reduces the geographic range of the impact relative to particulate nitrates P. Bickel (pers. comm., 2004).

The relative changes found in our calculations were compared with the values given in [20], Table $\mathbf{1}$ for Belgium $(1990-2010)$. The change they report for nitrates is very similar (93\% versus $96 \%$ increase in this calculation). The increase in cost per tonne of $\mathrm{SO}_{2}$ through exposure to sulphates was only predicted to increase by $6 \%-18 \%$ by [20], while it was seen to increase $87 \%$ in this trial. The most likely explanation for this difference is that different background concentrations were used as emissions predictions for 2010 were updated by EMEP. It proved however impossible to find out exactly which data had been used and compare it with our approach. The continuous update of background emission files and the use of the correct files for the questions under study should therefore be a constant point of attention. Authors should always state which background emissions were used and be aware of the consequences of using outdated background emissions for their results. The issue of changing background emissions is probably even more important for ozone formation and its impacts (see [20] for a discussion).

\section{Implications for the Results Published in the ExternE Transport Project}

Results from the ExternE transport project [5] have widely been used by policy makers to decide on the best automotive technologies (from an environmental point of view) and to estimate total savings from different policy proposals (by linear aggregation of incremental externalities). Implicitly external costs per tonne of pollutant calculated for a given year (often 1990 or 1994) were used to estimate avoided externalities in the future. Nevertheless it is important to take into account changes in atmospheric conditions when analyzing policy decisions that take their full effect in 2010 or later. Using external cost data obtained with software using 1990 or 1994 background emissions could yield spurious results, depending on which pollutants (primary or secondary) cause the dominant impacts.

To demonstrate the relevance of our main result to practical problems, we have recalculated the external costs for a diesel car driven in the centre of Brussels (Belgium), one of the case studies explored in detail in [15]. The results shown in Fig. (4) (expressed as $€$-cents per vehicle.km) were obtained by multiplication of the cost per tonne and specific emission factors. Only results for secondary pollutants are shown. Direct health impacts from $\mathrm{SO}_{2}$ and impacts on soil are so small that they are indiscernible on this scale. It is clear that for the analysis of transportation problems the changing value of sulphate impacts can be neglected when compared to increasing nitrate impacts. The sulphur content of all currently available transportation fuels has become so low under European fuel standards that the impacts have become very small. Impacts attributed to $\mathrm{NO}_{\mathrm{x}}$ emissions could in this case be approximately $0,3 €$-cent higher than previously reported. Obviously the total cost per $\mathrm{km}$ is less sensitive to the non-linearity of the secondary aerosol formation. Depending on the magnitude of impacts resulting from 


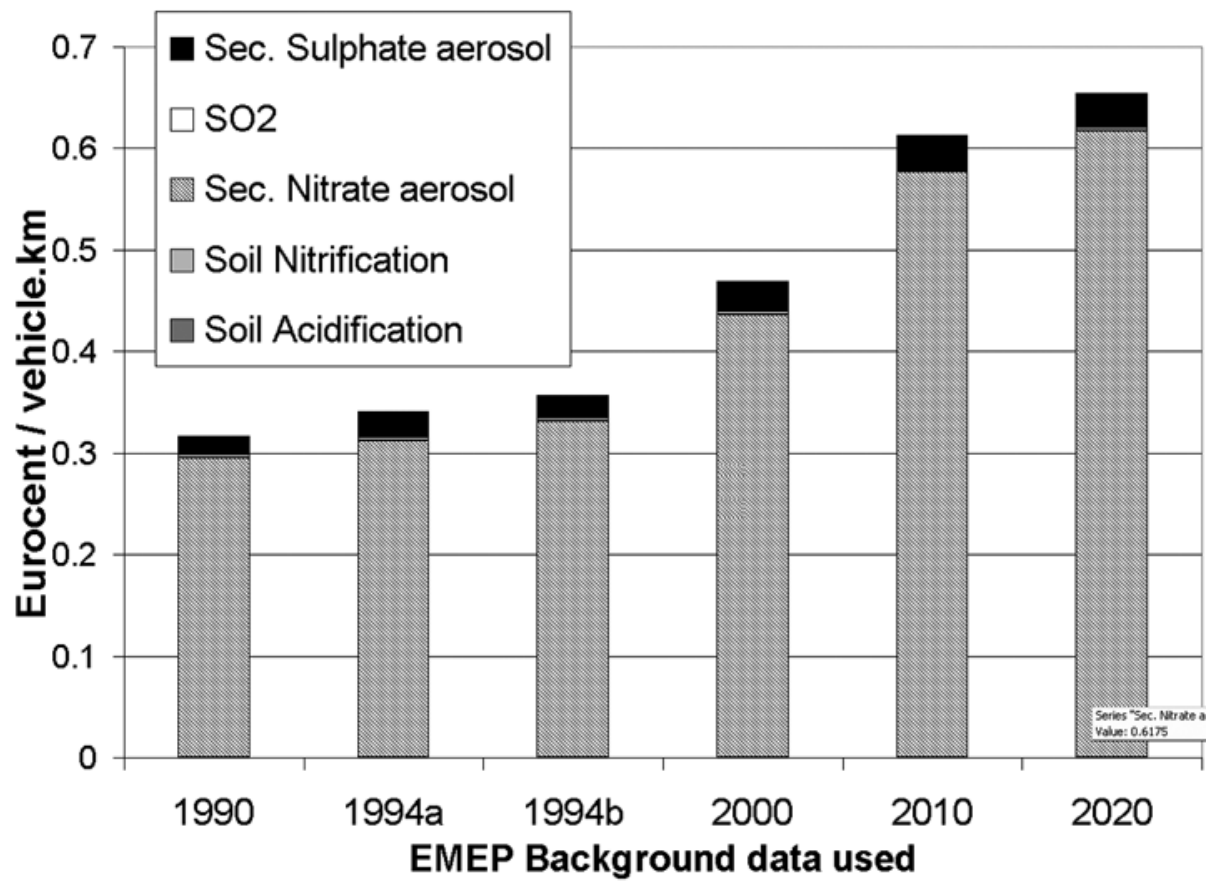

Fig. (4). Results for the regionally acting pollutants (from Belgian case study of a 10km trajectory through Brussels, ExternE 1998 [15].

primary emissions this may or may not be an important difference. For the majority of the results published in ExternE transport [5] primary PM emissions accounted for the largest share of the total impacts by far, and changing the value for nitrate would not have a significant effect on the total costs.

On the other hand with the increased use of particulate filters in advanced and future vehicles, the comparison of technologies and modes for future years often depends on a correct estimate for the external effects of $\mathrm{NO}_{\mathrm{x}}[21]$.

\section{Implications for Industrial Emissions from High Stacks}

As for transport, results from the ECOSENSE point source model have been widely used to compare different technologies for electricity production. European energy policy has partly been influenced by results from the ExternE projects. We believe that the ECOSENSE point source model behaves very similar to what was demonstrated in this paper for transport related problems (see also [20]). Nevertheless there are some important differences. Emissions from power plants are mostly emitted from high stacks that are some distance away from populated areas whereas exhaust gases from traffic are sometimes contained within street canyons before being dispersed. The sulphur content of the fuels used is also considerably higher than that of present day transportation fuels. The external costs of power plants are therefore dominated by impacts from secondary pollutants. The correct use of relevant background emissions with ECOSENSE point source is therefore even more important for applications focusing on power plants.

\section{CONCLUSION}

The most important new finding in this paper is that the external costs caused by ammonium sulphate and ammonium nitrate in the future (formed from the emission of $\mathrm{NO}_{\mathrm{x}}$ ) are underestimated when using wrong background emissions with ECOSENSE or any other model.

There is some uncertainty because the magnitude of this effect depends on how nitric acid is dealt with in the epidemiological calculations. If nitric acid is considered not to be toxic, incremental health impacts of secondary nitrogen species will more than double between 1990 and 2010. If on the other hand nitric acid is attributed with adverse health effects, present day impacts are underestimated, but the expected relative increase in the future will be smaller. External costs from $\mathrm{SO}_{2}$ emissions (through the adverse effects of ammonium sulphate on public health) will increase by $87 \%$ between 1994 and 2010.

Given the dominance of $\mathrm{PM}_{2.5}$ and other locally acting pollutants, results generated for present transport technologies show little change.

However, the results presented here are highly relevant for calculations related to advanced vehicles such as gasoline-electric hybrids and diesels with particulate filters.

Because of the relative importance of secondary pollutants for point source emissions from high stacks, changes to the externalities from power plants are expected to be important.

The findings presented in this paper will therefore be used to produce more accurate estimates of externalities within the ongoing ExternE projects NEEDS and CASES $(6 \mathrm{FP})$.

\section{ACKNOWLEDGEMENTS}

Discussions with Peter Bickel and Ari Rabl contributed to the results presented in this paper. 
The author also wishes to thank Rudi Torfs, Leo De Nocker, Daan Beheydt, Carolien Beckx and four anonymous reviewers for their useful comments on earlier versions of this paper. This work was partly funded under the European ExternE-POL project in the ExternE series.

\section{REFERENCES}

[1] ExternE. Externalities of Energy. National Implementation. Brussels: European Commission EC DGXII, Science Research and Development, 1999; EUR 18528: 606 pp. 606

[2] Brizio E, Genon G. The influence of different mixing heights on the ECOSENSE model results at a local scale. Environ Model Software 2005; 20(7): 917-33.

[3] Derwent R, Nodop K. Long-range transport and deposition of acidic nitrogen species in north-west Europe. Nature 1986; 324: 356-8.

[4] Derwent R, Dollard G, Metcalfe S. On the nitrogen budget for the United Kingdom and north-west Europe. QJR Meteorol Soc 1988; 114: 1127-52.

[5] Friedrich R, Bickel P, Ed. Environmental External Costs of Transport. Heidelberg: Springer Verlag, 2001.

[6] Int Panis L, Deutsch F, Torfs R. Factors contributing to the uncertainty of secondary particulates externalities: 2006: Proceedings of the $2^{\text {nd }}$ International Conference on Quantified Eco-Efficiency Analysis for Sustainability: 2006; Egmond aan Zee, The Netherlands.

[7] Griffin R, Dabdub D, Seinfeld J. Secondary organic aerosol 1. Atmospheric chemical mechanism for production of molecular constituents. J Geophys Res 2002; 107(D17): 4332.

[8] Pun B, Griffin R, Seigneur C, Seinfeld J. Secondary organic aerosol 2. Thermodynamic model for gas/particle partitioning of molecular constituents. J Geophys Res 2002; 107(D17): 4333.

[9] Zhang Y, Pun B, Vijayaraghavan K, et al. Development and application of the Model of Aerosol Dynamics, Reaction, Ionization, and Dissolution (MADRID). J Geophys Res 2004; 109: D01202.
[10] WHO. WHO air quality guidelines global update: WHO Regional Office for Europe, Denmark, 2005.

[11] Rabl A, Hurley F. Impact Pathway approach: Exposure Response functions. In: Bickel P, Friedrich R, Ed. ExternE Externalities of Energy, Methodology 2005 Update. Brussels: European Commission, DG Research 2005; 270.

[12] Pope C, Burnett R, Thun M, et al. Lung cancer, cardiopulmonary mortality and long-term exposure to fine particulate air pollution. $\mathrm{J}$ Amer Med Assoc 2002; 287(9): 1132-41.

[13] Abbey D, Lebowitz M, Mills P, Petersen F, Lawrence Beeson W, Burchette R. Long-term ambient concentrations of particulates and oxidants and development of chronic disease in a cohort of non smoking California residents. Inhal Toxicol 1995; 7: 19-34.

[14] ExternE. Methodology Report, 2nd Edition Volume 7. Brussels: European Commission EC DGXII. Sci Res Develop 1998.

[15] Int Panis L, De Nocker L. Marginal Costs Belgium. In: Friedrich R, Bickel P, Ed. Environmental External Costs of Transport. Heidelberg: Springer Verlag 2001; 169-73.

[16] Int Panis L. Impacts on crops. In: Bickel P, Friedrich R, Ed. ExternE Externalities of Energy, Methodology 2005 Update. Brussels: European Commission. DG Res 2005: 270.

[17] Bonnefous S, Despres A. Evolution of the European data base: IPSN/EURATOM - CEA Association, BP 6, 92265 Fontenay-AuxRoses, France, 1989.

[18] Erisman J, Schaap M. The need for ammonia abatement with respect to secondary PM reductions in Europe. Envir Pollut. 2004; 129: $159-63$

[19] GARPII. Green Accounting In Europe, A Comparative Study. Edgar Elgar, Cheltenham: The Fondazione Eni Enrico Mattei (FEEM); 2005; Vol 2.

[20] Krewitt W, Trukenmuller A, Bachman TM, Heck T. Countryspecific damage factors for air pollutants. Int J LCA 2001; 6(4): 199-210.

[21] Int Panis L, De Nocker L, De Vlieger I, Torfs R. Trends and uncertainty in air pollution impacts and external costs of Belgian passenger car traffic. Int J Vehicle Des 2001; 27(1-4): 183-94.

(C) L.L.R. Int Panis; Licensee Bentham Open .

This is an open access article distributed under the terms of the Creative Commons Attribution License (http://creativecommons.org/license/by/2.5/), which permits unrestrictive use, distribution, and reproduction in any medium, provided the original work is properly cited. 